\title{
A Fragmentation Study on Four Oligostilbenes by Electrospray Tandem Mass Spectrometry
}

\author{
Chen-Chen Zhang ${ }^{1,2,3} \cdot$ Chang-An Geng ${ }^{1,2} \cdot$ Ji-Jun Chen ${ }^{1,2,3}$ (i)
}

Received: 23 April 2019 / Accepted: 14 May 2019 / Published online: 22 May 2019

(c) The Author(s) 2019

\begin{abstract}
Oligostilbenes have attracted much interest due to their intricate structures and diverse bioactivities. In this study, two stilbene dimers, (-)-7,8-cis- $\varepsilon$-viniferin (1) and carasiphenol A (2), and two trimers, suffruticosol A (3) and suffruticosol C (4), were investigated by electrospray ionization ion-trap time-of-flight multistage mass spectrometry (ESI-IT-TOF-MS ${ }^{\mathrm{n}}$ ). Based on the $\mathrm{MS}^{\mathrm{n}}$ study, the fragmentation pathways and diagnostic ions of four oligostilbenes in both positive and negative modes were proposed. The consecutive elimination of phenol $\left(\mathrm{C}_{6} \mathrm{H}_{6} \mathrm{O}\right)$ and resorcinol $\left(\mathrm{C}_{6} \mathrm{H}_{6} \mathrm{O}_{2}\right)$ moieties were the particular dissociation for oligostilbenes due to the presence of 1,2-diphenylethylene nucleus. The present $\mathrm{MS}^{\mathrm{n}}$ fragmentation study will provide valuable information for the fast characterization of oligostilbenes from complicated natural mixtures.
\end{abstract}

\section{Graphical Abstract}

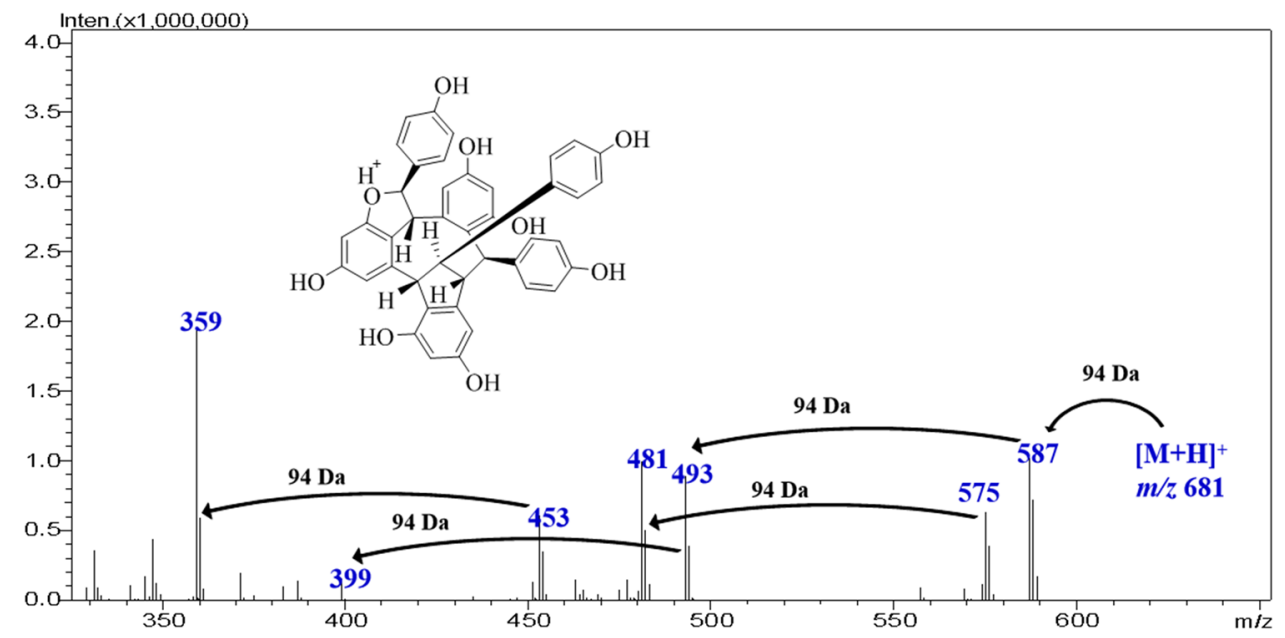

Keywords ESI-IT-TOF-MS ${ }^{\mathrm{n}} \cdot$ Fragmentation rules $\cdot$ Oligostilbenes

\section{Introduction}

Electronic supplementary material The online version of this article (https://doi.org/10.1007/s13659-019-0212-3) contains supplementary material, which is available to authorized users.

Chang-An Geng

gengchangan@mail.kib.ac.cn

Ji-Jun Chen

chenjj@mail.kib.ac.cn

Extended author information available on the last page of the article
Natural stilbenes are an important group of polyphenols characterized by the presence of 1,2-diphenylethylene nucleus [1]. Naturally occurring stilbenes always have intricate structures with different numbers of stilbenes and polymeric types [2]. Stilbenes as the defensive chemicals of plants are revealed with diverse bioactivities including anti-tumor, anti-oxidant, anti-inflammatory, 
anti-fungal, anti-diabetic and anti-Alzheimer's disease effects [3-7], whereas their natural distribution is quite limited, mainly in Cyperaceae, Dipterocarpaceae, Gnetaceae, Iridaceae, Leguminosae, Moraceae, Orchidaceae and Polygonaceae plants [2]. Thus, it is necessary to develop and establish a rapid and systematic method to profile stilbenes from natural resources.

Mass spectrometry (MS) with high sensitivity and resolution is one of the most efficient method in analyzing natural products [8-10]. Tandem MS techniques have advantages in ascertaining the relationship between precursor and product ions, by which the fragmentation rules and diagnostic ions of complicated compounds can be proposed $[11,12]$. In this paper, we report the $\mathrm{MS}^{\mathrm{n}}$ fragmentation rules of four oligostilbenes, (-)-7,8-cis- $\varepsilon$ viniferin (1), carasiphenol A (2), suffruticosol A (3) and suffruticosol C (4), by electrospray ionization ion-trap time-of-flight (ESI-IT-TOF) mass spectrometer to provide reference for their fast characterization from natural sources.

\section{Results and Discussion}

The first-stage MS of compounds 1-4 (Fig. 1) in both positive and negative ion modes were acquired in automatic pattern, by which their protonated $\left([\mathrm{M}+\mathrm{H}]^{+}\right)$and deprotonated $\left([\mathrm{M}-\mathrm{H}]^{-}\right)$molecule ions were readily detected. For compounds $\mathbf{1}, 3$ and $\mathbf{4}$, the $[\mathrm{M}+\mathrm{HCOO}]^{-}$ions in negative mode were also obtained due to the application of formic acid in the solvent [13]. The subsequent $\mathrm{MS}^{\mathrm{n}}$ studies on compounds 1-4 in both positive and negative modes were performed, from which their fragmentation pathways were proposed (Figs. 2, 3, 4, 5, 6, 7, 8, 9). It should be noted that alternative ways of fragmentation that can reasonably interpret the product ions are also possible in addition to the proposed pathway. For example, the negative charge can be present at any hydroxy group rather than the position denoted.

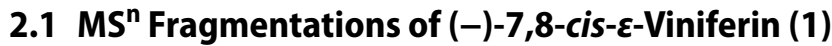 in Positive Mode}

In the single-stage mass spectrum of (-)-7,8-cis$\varepsilon$-viniferin (1), the $[\mathrm{M}+\mathrm{H}]^{+}$ion at $\mathrm{m} / \mathrm{z} 455(\mathbf{1 A})$, $[\mathrm{M}-\mathrm{H}]^{-}$ion at $\mathrm{m} / \mathrm{z} 453(\mathbf{1 b})$ and $[\mathrm{M}+\mathrm{HCOO}]^{-}$ion at

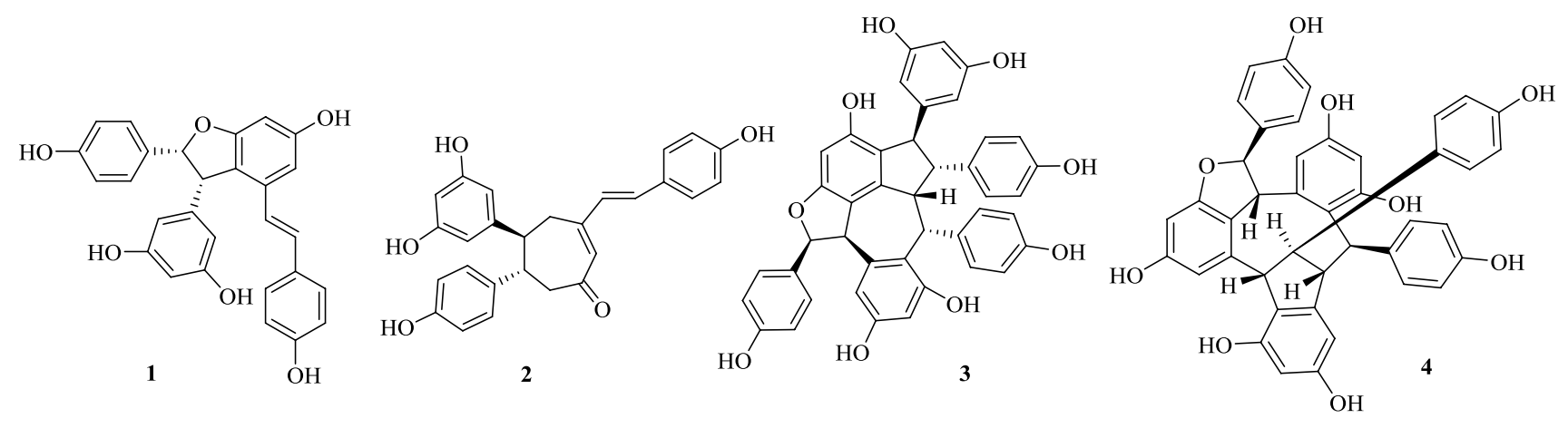

Fig. 1 Structures of compounds $\mathbf{1}-\mathbf{4}$

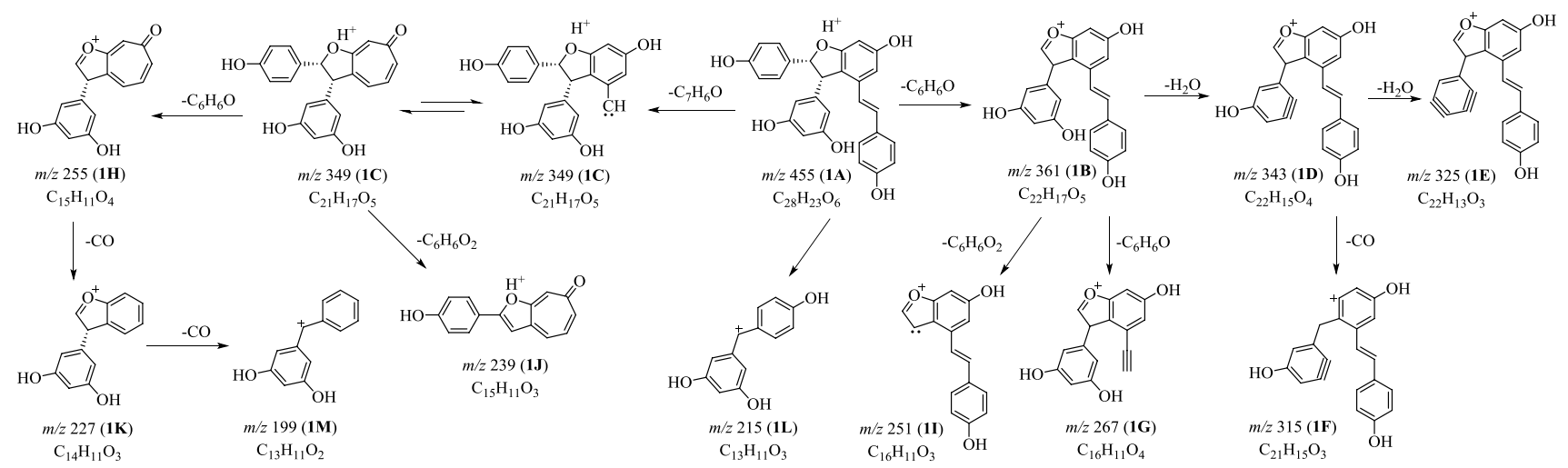

Fig. 2 Proposed fragmentation pathways of (-)-7,8-cis- $\varepsilon$-viniferin (1) in positive mode 


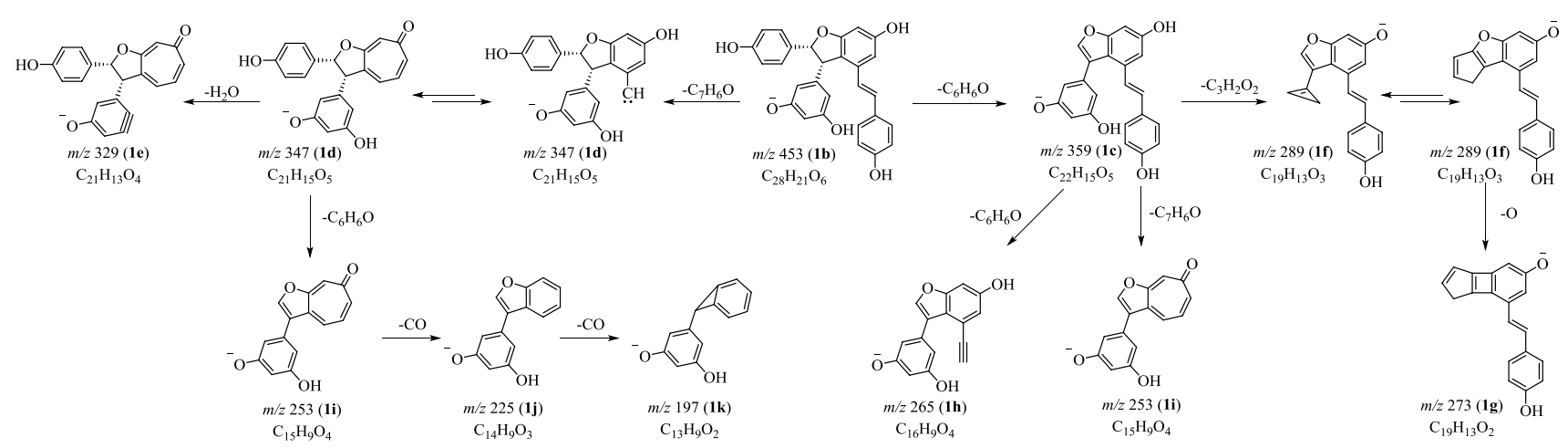

Fig. 3 Proposed fragmentation pathways of (-)-7,8-cis- $\varepsilon$-viniferin (1) in negative mode

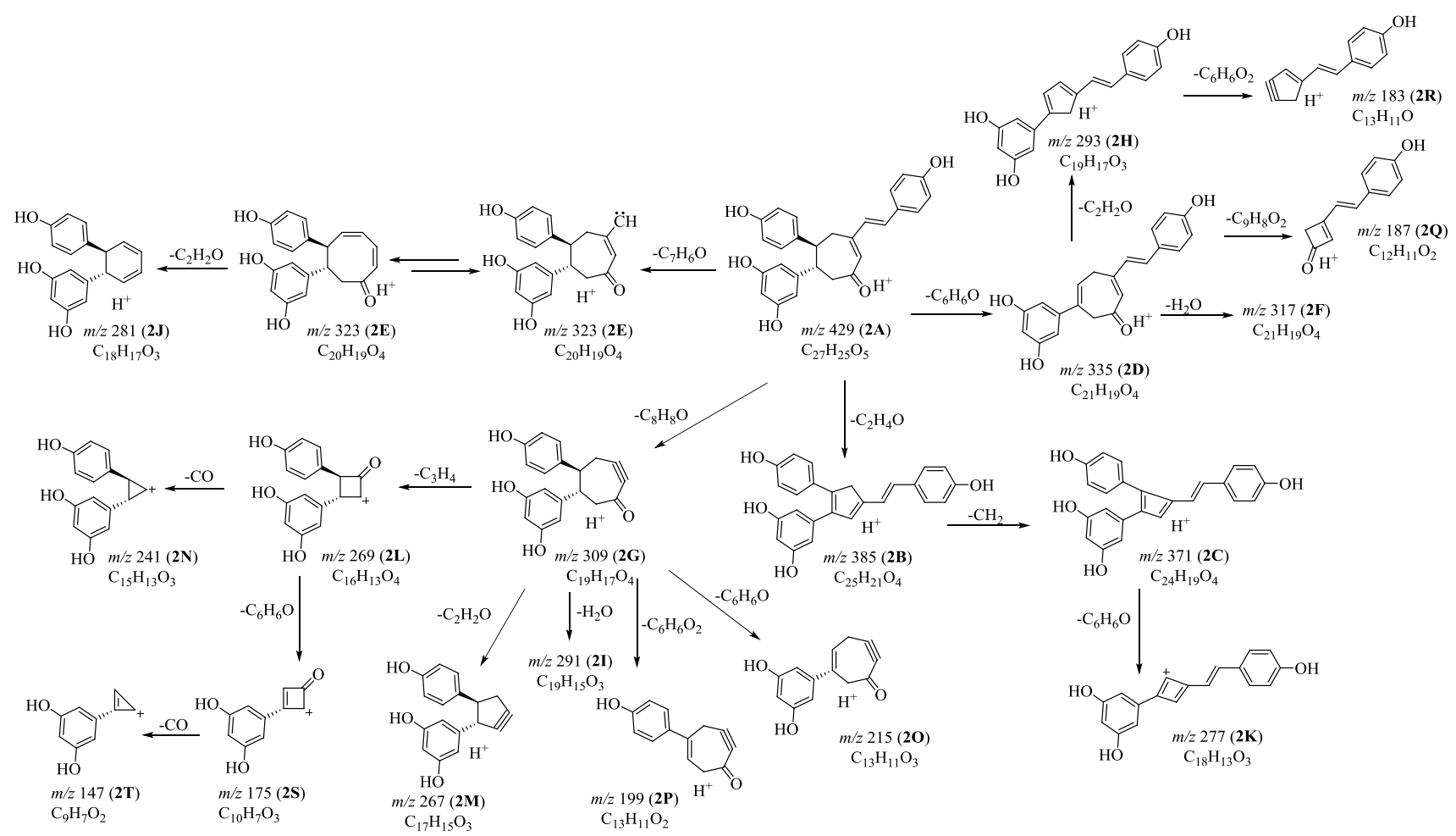

Fig. 4 Proposed fragmentation pathways of carasiphenol A (2) in positive mode

$\mathrm{m} / z 499$ (1a) were readily obtained, corresponding to the molecular formula of $\mathrm{C}_{28} \mathrm{H}_{22} \mathrm{O}_{6}$. The subsequent $\mathrm{MS}^{2}$ experiment on $[\mathrm{M}+\mathrm{H}]^{+}(\mathbf{1} \mathbf{A})$ gave rise to multiple product ions (1B-1L). The ion $\mathbf{1 A}$ lost a $\mathrm{C}_{6} \mathrm{H}_{6} \mathrm{O}$ or a $\mathrm{C}_{7} \mathrm{H}_{6} \mathrm{O}$ moiety to provide the ions of $\mathbf{1 B}(\mathrm{m} / \mathrm{z} 361)$ and $\mathbf{1 C}(\mathrm{m} / \mathrm{z}$ 349) [14]. Then, the subsequent elimination of two $\mathrm{H}_{2} \mathrm{O}$ molecules from $1 B$ generated ions at $\mathrm{m} / z 343$ and $\mathrm{m} / \mathrm{z} 325$. The ion $1 \mathrm{C}$ was present in high abundance, which might be due to the rearrangement of $\mathbf{1 C}$ into tropone derivative. The ions 1G $(\mathrm{m} / \mathrm{z} 267)$ and $\mathbf{1 I}(\mathrm{m} / \mathrm{z} 251)$ were proposed from $1 \mathrm{~B}$ by the elimination of $\mathrm{C}_{6} \mathrm{H}_{6} \mathrm{O}$ or a $\mathrm{C}_{6} \mathrm{H}_{6} \mathrm{O}_{2}$ part.
The similar fragmentation was also observed for ion 1C, from which two product ions at $\mathrm{m} / \mathrm{z} 255$ (1H) and $\mathrm{m} / \mathrm{z}$ 239 (1J) were obtained corresponding to neutral loss of a $\mathrm{C}_{6} \mathrm{H}_{6} \mathrm{O}$ or a $\mathrm{C}_{6} \mathrm{H}_{6} \mathrm{O}_{2}$ part. When ion $\mathbf{1 H}$ was selected as the precursor ion to perform $\mathrm{MS}^{3}$ experiment, two ions $\mathbf{1 K}(\mathrm{m} / \mathrm{z} 227)$ and $\mathbf{1} \mathbf{M}(\mathrm{m} / \mathrm{z} 199)$ were formed by the successive loss of two CO molecules. Similarly, the ion $\mathbf{1 F}$ $(\mathrm{m} / \mathrm{z}, 315)$ was well explained by the loss of a molecule of CO from 1D [15-17]. In addition, a $\mathrm{MS}^{2}$ ion at $m / z 215$ (1L) was also observed from $\mathbf{1 A}$, but its fragmentation pathway was still unclear (Fig. 2). 


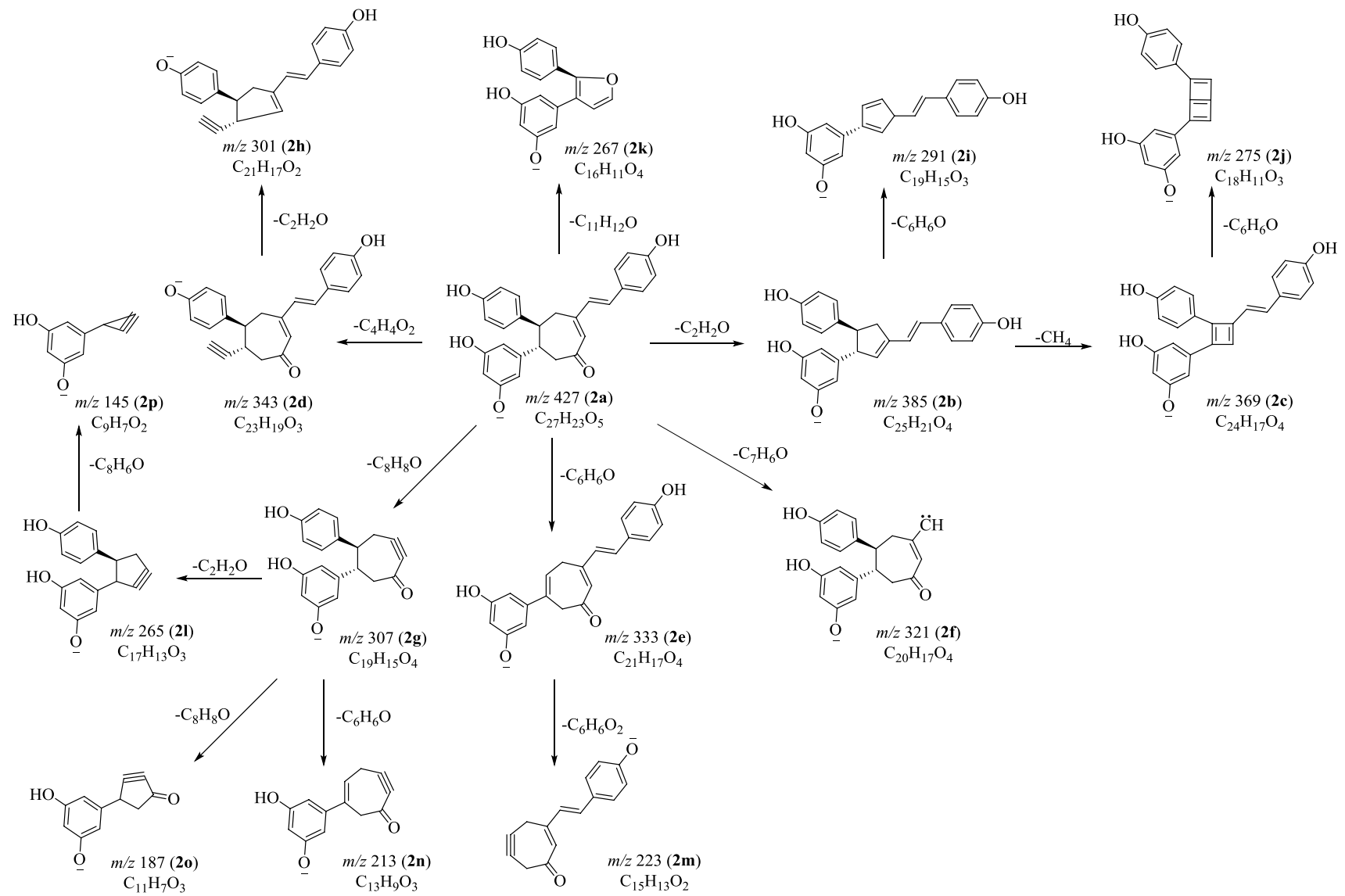

Fig. 5 Proposed fragmentation pathways of carasiphenol A (2) in negative mode

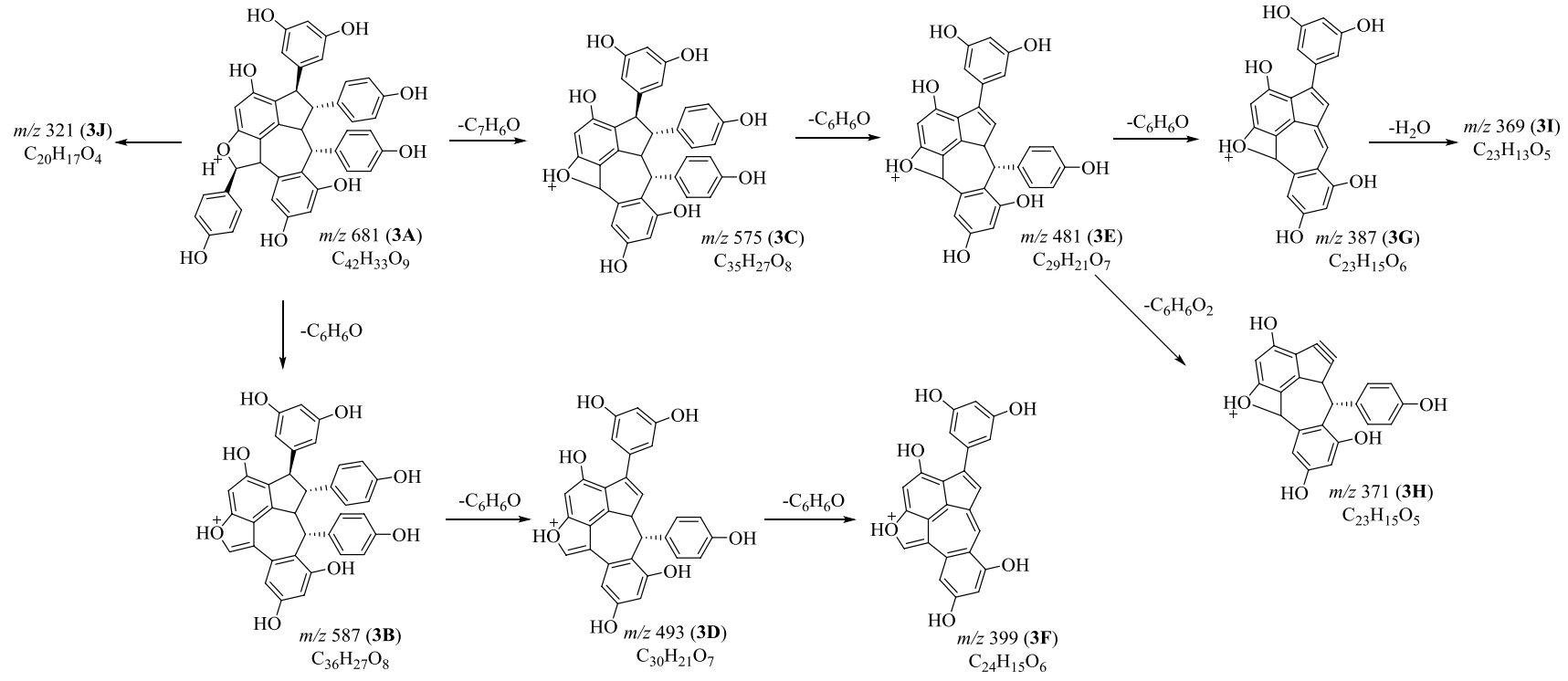

Fig. 6 Proposed fragmentation pathways of suffruticosol A (3) in positive mode 


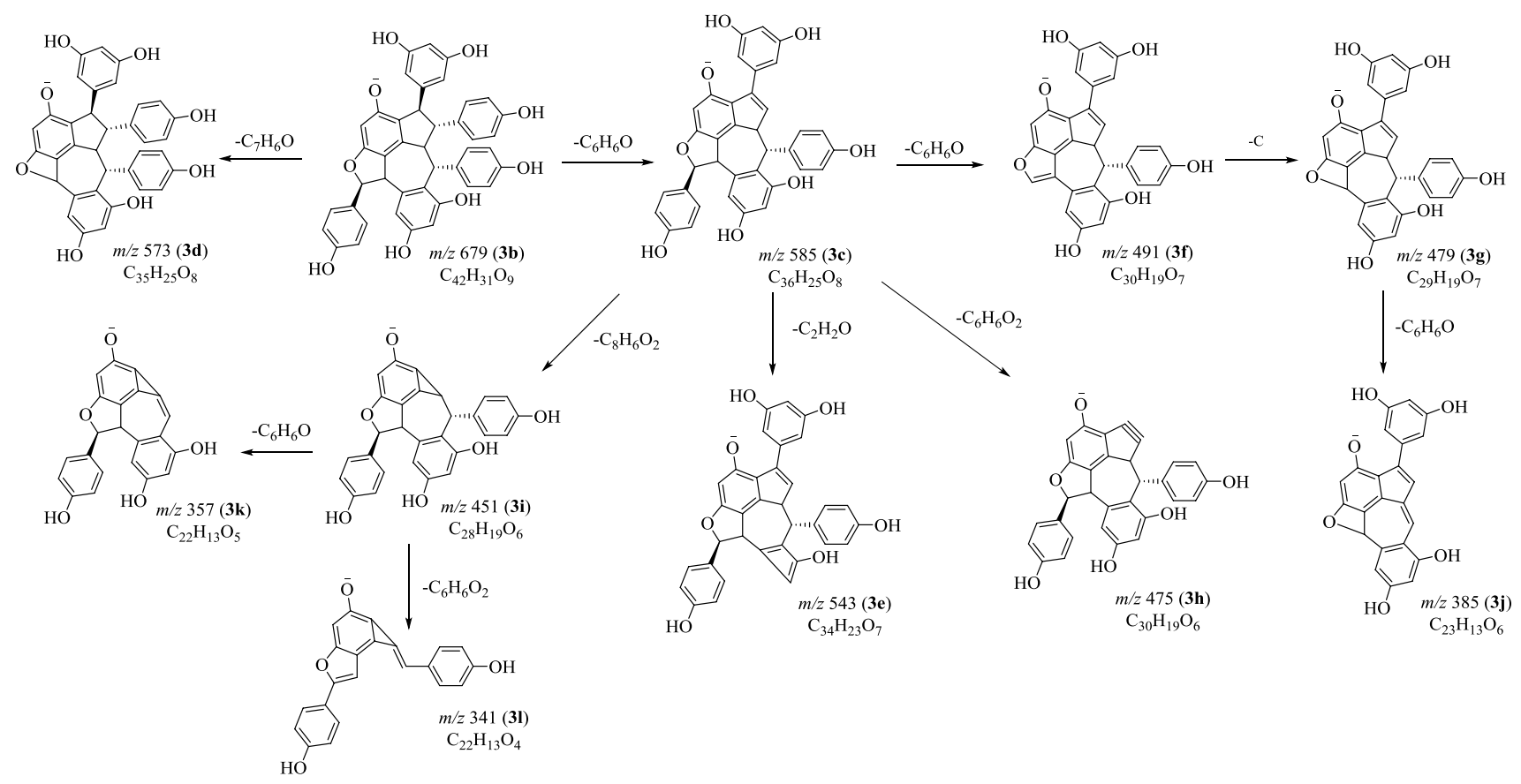

Fig. 7 Proposed fragmentation pathways of suffruticosol A (3) in negative mode

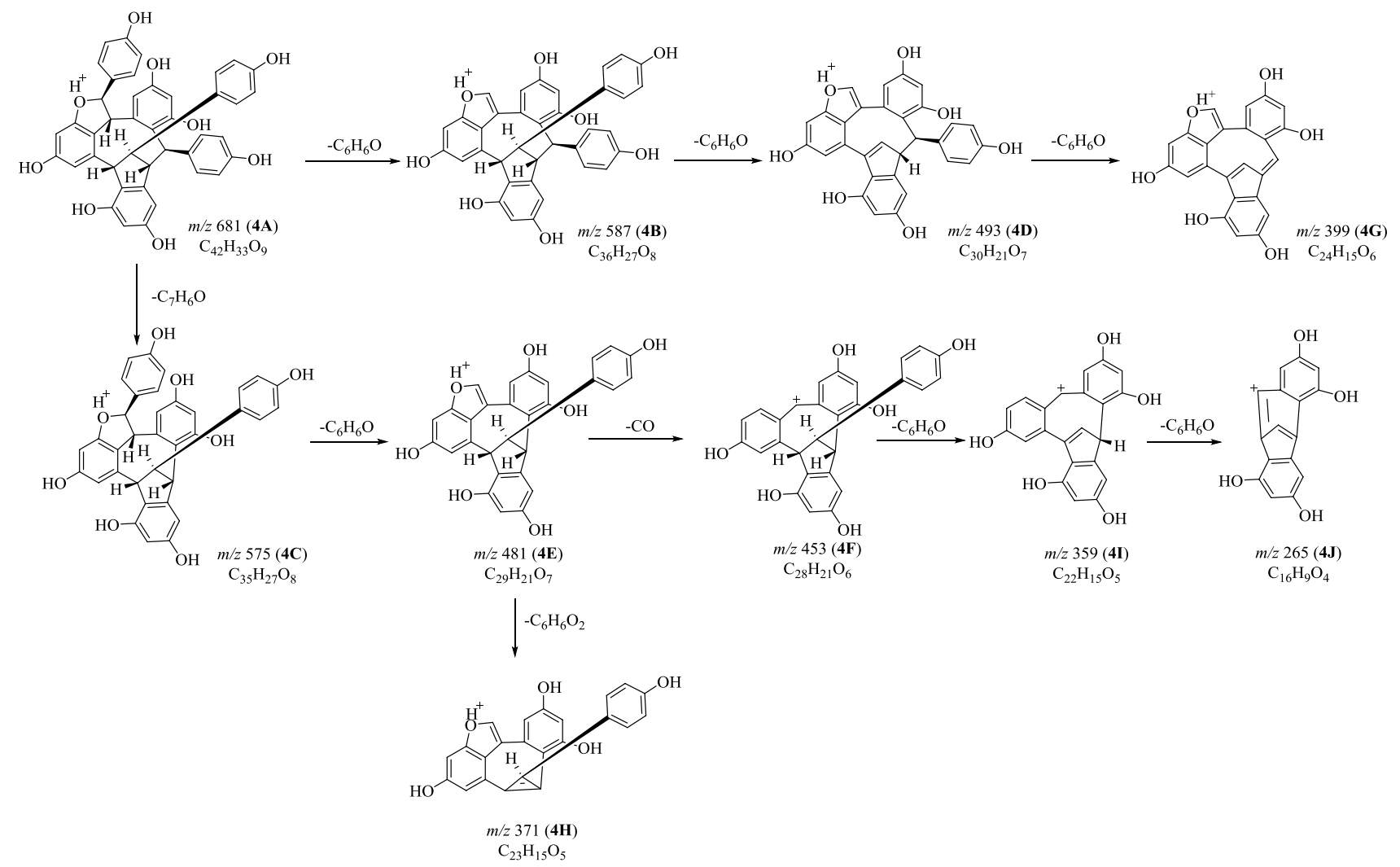

Fig. 8 Proposed fragmentation pathways of suffruticosol C (4) in positive mode 


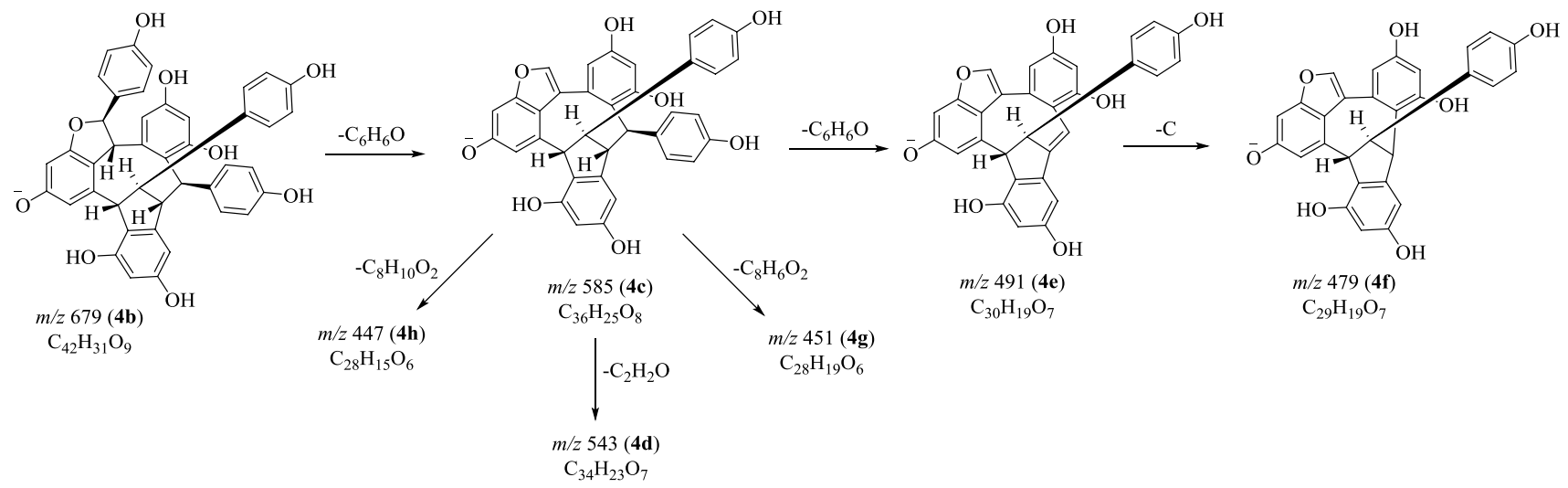

Fig. 9 Proposed fragmentation pathways of suffruticosol C (4) in negative mode

\subsection{MS $^{\mathrm{n}}$ Fragmentations of (-)-7,8-cis- $\varepsilon-V i n i f e r i n ~(1)$ in Negative Mode}

Similar to that in positive mode, the $[\mathrm{M}-\mathrm{H}]^{-}$ion $\mathbf{1 b}$ gave rise to ions at $\mathrm{m} / \mathrm{z} 359$ (1c) and $\mathrm{m} / \mathrm{z} 347$ (1d) by the loss of a $\mathrm{C}_{6} \mathrm{H}_{6} \mathrm{O}$ or a $\mathrm{C}_{7} \mathrm{H}_{6} \mathrm{O}$ moiety. When ion $1 \mathrm{c}$ was chosen to perform $\mathrm{MS}^{3}$ experiment, three product ions at $m / z 289$ (1f), $\mathrm{m} / z 265$ (1) and $\mathrm{m} / z 253$ (1i) were obtained, corresponding to the elimination of $\mathrm{C}_{3} \mathrm{H}_{2} \mathrm{O}_{2}, \mathrm{C}_{6} \mathrm{H}_{6} \mathrm{O}$ and $\mathrm{C}_{7} \mathrm{H}_{6} \mathrm{O}$ moieties [15-17]. The $\mathrm{MS}^{3}$ study on $\mathbf{1 d}$ provided ions $\mathbf{1 i}(\mathrm{m} / \mathrm{z} 253)$ and $\mathbf{1 j}(\mathrm{m} / \mathrm{z} 225)$ in accordance with the departure of $\mathrm{C}_{6} \mathrm{H}_{6} \mathrm{O}$ and $\mathrm{C}_{7} \mathrm{H}_{6} \mathrm{O}_{2}$ parts. The ions at $m / z 273(\mathbf{1 g})$ and $\mathrm{m} / z 197(\mathbf{1 k})$ were tentatively deduced from $\mathbf{1} \mathbf{f}$ and $\mathbf{1} \mathbf{j}$ by the loss of an $\mathrm{O}$ or a $\mathrm{CO}$ moiety. Due to the presence of hydroxy groups in the structure, the elimination of $\mathrm{H}_{2} \mathrm{O}$ from $1 d$ generated 1e (Fig. 3).

\subsection{MS $^{\mathrm{n}}$ Fragmentations of Carasiphenol A (2) in Positive Mode}

The $[\mathrm{M}+\mathrm{H}]^{+}$ion $2 \mathrm{~A}$ gave rise to fragments at $\mathrm{m} / z 385(\mathbf{2 B})$, $\mathrm{m} / \mathrm{z} 335(\mathbf{2 D})$ and $323(\mathbf{2 E})$ by the elimination of $\mathrm{C}_{2} \mathrm{H}_{4} \mathrm{O}$, $\mathrm{C}_{6} \mathrm{H}_{6} \mathrm{O}$ and $\mathrm{C}_{7} \mathrm{H}_{6} \mathrm{O}$ moieties [15-17]. The ion $\mathbf{2 E}$ might undergo a rearrangement and further loss a $\mathrm{C}_{2} \mathrm{H}_{2} \mathrm{O}$ part to provide $\mathbf{2 J}(\mathrm{m} / \mathrm{z} 281)$. By the loss of a $\mathrm{CH}_{2}$ part from $\mathbf{2 B}$, the ion at $\mathrm{m} / z 371$ (2C) was yielded, and further provided ion $2 \mathrm{~K}(\mathrm{~m} / \mathrm{z}, 277)$ by the loss of $\mathrm{C}_{6} \mathrm{H}_{6} \mathrm{O}$ moiety. When the ion at $m / z, 309$ (2G) was chosen for $\mathrm{MS}^{3}$ experiment, diverse ions at $\mathrm{m} / \mathrm{z} 291$ (2I), 267 (2M), 215 (20) and 199 (2P) were obtained. The ion at $\mathrm{m} / z 269$ (2L) was deduced from $2 \mathbf{G}$ by the elimination of $\mathrm{C}_{3} \mathrm{H}_{4}$ part. The subsequent $\mathrm{MS}^{3}$ study on 2L generated ions at $m / z, 241$ (2N), 175 (2S) and 147 (2T). With the elimination of $\mathrm{H}_{2} \mathrm{O}, \mathrm{C}_{2} \mathrm{H}_{2} \mathrm{O}$ or $\mathrm{C}_{9} \mathrm{H}_{8} \mathrm{O}_{2}$ part from 2D, three ions at $m / z 317(\mathbf{2 F}), 293(\mathbf{2 H})$ and $187(\mathbf{2 Q})$ were obtained. The ion at $\mathrm{m} / \mathrm{z} 183(\mathbf{2 R})$ was tentatively deduced from $\mathbf{2 H}$ by the loss of resorcinol moiety (Fig. 4).

\subsection{MS ${ }^{\mathrm{n}}$ Fragmentations of Carasiphenol A (2) in Negative Mode}

The $\mathrm{MS}^{2}$ experiment on $[\mathrm{M}-\mathrm{H}]^{-}$ion generated prolific fragments at $\mathrm{m} / z 385$ (2b), 369 (2c), 343 (2d), 333 (2e), 321 (2f), 307 (2g) and 267 (2k). The following MS $^{3}$ experiment on $\mathbf{2 b}$ and $\mathbf{2 c}$ gave rise to $\mathbf{2} \mathbf{i}(\mathrm{m} / \mathrm{z} 291)$ and $\mathbf{2 j}(\mathrm{m} / \mathrm{z} 275)$, respectively, corresponding to the neutral loss of a phenol moiety. The ions at $\mathrm{m} / \mathrm{z} 301$ (2h) and $223(\mathbf{2 m})$ were produced from the precursors $\mathbf{2 d}$ and $\mathbf{2 e}$, by the elimination of $\mathrm{C}_{2} \mathrm{H}_{2} \mathrm{O}$ and $\mathrm{C}_{6} \mathrm{H}_{6} \mathrm{O}_{2}$ [15-17]. When ion at $m / z 307(2 \mathrm{~g})$ was performed the $\mathrm{MS}^{3}$ study, three ions at $\mathrm{m} / z, 265$ (2l), $\mathrm{m} / z, 213$ (2n) and $m / z 187$ (2o) were formed. The ion $\mathbf{2 p}(\mathrm{m} / \mathrm{z}$ 145) was affirmed from the precursor $\mathbf{2 l}$ by the loss of a molecule of $\mathrm{C}_{8} \mathrm{H}_{6} \mathrm{O}$ (Fig. 5).

\subsection{MS ${ }^{n}$ Fragmentations of Suffruticosol A (3) in Positive Mode}

The $\mathrm{MS}^{2}$ study on $[\mathrm{M}+\mathrm{H}]^{+}$ion gave rise to the fragments at $\mathrm{m} / \mathrm{z} 587$ (3B), 575 (3C), 493 (3D), 481 (3E) and 321 (3J). The production of ion $\mathbf{3 E}(\mathrm{m} / \mathrm{z}, 481)$ was verified as the successive elimination of a $\mathrm{C}_{7} \mathrm{H}_{6} \mathrm{O}$ and $\mathrm{a}_{6} \mathrm{H}_{6} \mathrm{O}$ part from $3 \mathrm{~A}$. The ion $3 \mathbf{E}$ could further generate ion at $\mathrm{m} / z 387(\mathbf{3 G})$ and $371(3 \mathrm{H})$ by the neutral loss of a phenol $\left(\mathrm{C}_{6} \mathrm{H}_{6} \mathrm{O}\right)$ and a resorcinol $\left(\mathrm{C}_{6} \mathrm{H}_{6} \mathrm{O}_{2}\right)$ moiety [15-17]. With the elimination of a molecule of $\mathrm{H}_{2} \mathrm{O}$, the ion at $m / z, 369$ (3I) was obtained from 3G. Similarly, the fragment $\mathbf{3 F}$ was produced from 3D by the loss of a phenol $\left(\mathrm{C}_{6} \mathrm{H}_{6} \mathrm{O}\right)$ part (Fig. 6).

\subsection{MS ${ }^{n}$ Fragmentations of Suffruticosol A (3) in Negative Mode}

When the $[\mathrm{M}-\mathrm{H}]^{-}$ion was chosen for $\mathrm{MS}^{2}$ study, the product ions at $\mathrm{m} / z 585$ (3c) and 573 (3d) were generated due to the loss of $\mathrm{C}_{6} \mathrm{H}_{6} \mathrm{O}$ and $\mathrm{C}_{7} \mathrm{H}_{6} \mathrm{O}$ moieties [15-17]. The following $\mathrm{MS}^{3}$ investigation on ion $3 \mathbf{c}$ gave rise to fragments at $\mathrm{m} / \mathrm{z}$ 
$543(\mathbf{3 e}), 491(\mathbf{3 f}), 479(\mathbf{3 g})$ and $475(\mathbf{3 h})$, which could be explained by the elimination of $\mathrm{C}_{2} \mathrm{H}_{2} \mathrm{O}, \mathrm{C}_{6} \mathrm{H}_{6} \mathrm{O}, \mathrm{C}_{7} \mathrm{H}_{6} \mathrm{O}$ and $\mathrm{C}_{6} \mathrm{H}_{6} \mathrm{O}_{2}$. The ion $\mathbf{3 j}(\mathrm{m} / \mathrm{z}, 385)$ was deduced from $\mathbf{3 g}$ by the neutral loss of a molecular of phenol $\left(\mathrm{C}_{6} \mathrm{H}_{6} \mathrm{O}\right)$ moiety. Two $\mathrm{MS}^{3}$ fragments at $m / z 357(\mathbf{3 k})$ and 341 (3l) were obtained from $3 \mathbf{i}$, which were well in accordance with the departure of a phenol $\left(\mathrm{C}_{6} \mathrm{H}_{6} \mathrm{O}\right)$ and a resorcinol $\left(\mathrm{C}_{6} \mathrm{H}_{6} \mathrm{O}_{2}\right)$ parts (Fig. 7).

\subsection{MS $^{\mathrm{n}}$ Fragmentations of Suffruticosol C (4) in Positive Mode}

The $[\mathrm{M}+\mathrm{H}]^{+}$ion of $\mathbf{4 A}$ gave rise to $\mathrm{MS}^{2}$ fragments at $\mathrm{m} / \mathrm{z}$ $587(4 \mathrm{~B})$ and $575(4 \mathrm{C})$ due to the neutral loss of a molecule of $\mathrm{C}_{6} \mathrm{H}_{6} \mathrm{O}$ and $\mathrm{C}_{7} \mathrm{H}_{6} \mathrm{O}$ parts. The successively loss of two $\mathrm{C}_{6} \mathrm{H}_{6} \mathrm{O}$ moieties was further observed in the $\mathrm{MS}^{3}$ experiment on ion $\mathbf{4 B}$, and thus gave rise to the fragments at $\mathrm{m} / \mathrm{z} 493$ (4D) and 399 (4G). The ions $\mathbf{4 E}(\mathrm{m} / \mathrm{z} 481)$ and $\mathbf{4 H}(\mathrm{m} / \mathrm{z} 371)$ were generated from $4 \mathrm{C}$ by the successive loss of $\mathrm{a}_{6} \mathrm{H}_{6} \mathrm{O}$ and a $\mathrm{C}_{6} \mathrm{H}_{6} \mathrm{O}_{2}$ moieties [15-17]. The ion at $m / z 453(\mathbf{4 F})$ was deduced from $4 \mathrm{E}$ by the elimination of a molecule of $\mathrm{CO}$, and further gave rise to $\mathbf{4 I}(\mathrm{m} / \mathrm{z} 359)$ and $\mathbf{4 J}(\mathrm{m} / \mathrm{z}, 265)$ which was well explained by the consecutive loss of two phenol $\left(\mathrm{C}_{6} \mathrm{H}_{6} \mathrm{O}\right)$ moieties. The ion at $m / z 371(\mathbf{4 H})$ was generated from $4 \mathrm{E}$ by the departure of $\mathrm{C}_{6} \mathrm{H}_{6} \mathrm{O}_{2}$ moiety (Fig. 8).

\subsection{MS $^{\mathrm{n}}$ Fragmentations of Suffruticosol C (4) in Negative Mode}

In the negative $\mathrm{MS}^{2}$ experiment, the neutral loss of $\mathrm{C}_{6} \mathrm{H}_{6} \mathrm{O}$ from the $[\mathrm{M}-\mathrm{H}]^{-}$ion $(\mathbf{4 b})$ gave rise to the fragment at $\mathrm{m} / \mathrm{z}$. $585(\mathbf{4 c})$. When the ion $4 \mathbf{c}$ was chosen to perform the $\mathrm{MS}^{3}$ study, diverse ions at $m / z 543,491,479,451$ and 447 were obtained. The ions $\mathbf{4 e}$ and $\mathbf{4 f}$ were well consistent with the elimination of $\mathrm{C}_{6} \mathrm{H}_{6} \mathrm{O}$ and $\mathrm{C}_{7} \mathrm{H}_{6} \mathrm{O}$ parts from the precursor $\mathbf{4 c}$ [15-17]. However, the formation of ions $\mathbf{4 d}(\mathrm{m} / \mathrm{z}, 543)$, $\mathbf{4 g}(\mathrm{m} / \mathrm{z} 451)$ and $\mathbf{4 h}(\mathrm{m} / \mathrm{z} 447)$ was difficult to explain due to the complicated structure (Fig. 9).

\section{Experimental}

\subsection{Apparatus and Analytical Conditions}

All of the MS ${ }^{\mathrm{n}}$ experiments were performed on the LCMSIT-TOF mass spectrometer (Shimadzu, Kyoto, Japan). Accurate masses were calibrated using sodium trifluoroacetate $\left(\mathrm{CF}_{3} \mathrm{CO}_{2} \mathrm{Na}\right)$ clusters. MS experiments were performed in automatic pattern, and $\mathrm{MS}^{\mathrm{n}}$ experiments were achieved in direct mode. The MS parameters are in accordance with the previous report [18].

\subsection{Chemicals and Samples}

Acetonitrile $\left(\mathrm{CH}_{3} \mathrm{CN}\right)$ of HPLC grade was purchased from Merck Co., Ltd., Germany, and formic acid was bought from Aladdin Chemistry Co., Ltd., China. Deionized water was purified using a MingChe ${ }^{\text {TM}}$-D 24UV Merck Millipore system (Merck Millipore, Shanghai, China). Compounds 1-4 were isolated from the seeds of Paeonia lactiflora Pall. in our previous investigation. Samples were diluted in $\mathrm{MeOH}$ at the concentration of $0.5 \mathrm{mg} / \mathrm{mL}$.

\section{Conclusion}

The ESI multi-stage mass spectra $\left(\mathrm{MS}^{\mathrm{n}}\right)$ of four oligostilbenes were studied for the first time by LCMS-IT-TOF, by which their fragmentation pathways were deduced. The consecutive elimination of phenol $\left(\mathrm{C}_{6} \mathrm{H}_{6} \mathrm{O}\right)$ and resorcinol $\left(\mathrm{C}_{6} \mathrm{H}_{6} \mathrm{O}_{2}\right)$ moieties from the precursor ions was the particular dissociation due to the presence of 1,2-diphenylethylene nucleus in the structure. Interestingly, the elimination of a $\mathrm{C}_{7} \mathrm{H}_{6} \mathrm{O}$ moiety was always detected due to the fracture of the double bond in 1,2-diphenylethylene nucleus, and this fragmentation pathway might be impelled by the rearrangement of the free radical into a stable conjugated system (e.g. tropone). Based on the fragmentation rules deduced above, (-)-7,8-cis- $\varepsilon$-viniferin (1), carasiphenol A (2), suffruticosol A (3) and suffruticosol C (4) could be well differentiated by their respective ion pars of 455-215, 429-267, 681-321 and 681-359 in positive mode, and 453-359, 427-307, 679-451 and 679-447 in negative mode. The present $\mathrm{MS}^{\mathrm{n}}$ fragmentation study will provide valuable information for the fast characterization of oligostilbenes from complicated natural mixtures.

Acknowledgements This work was financially supported by the National Natural Science Foundation of China (81773609), the Program of Yunling Scholarship, and the Applied Basic Research Programs of Yunnan Province (2017FB137).

\section{Compliance with Ethical Standards}

Conflict of interest These authors have no conflict of interest to declare.

Open Access This article is distributed under the terms of the Creative Commons Attribution 4.0 International License (http://creativeco mmons.org/licenses/by/4.0/), which permits unrestricted use, distribution, and reproduction in any medium, provided you give appropriate credit to the original author(s) and the source, provide a link to the Creative Commons license, and indicate if changes were made. 


\section{References}

1. C. Riviere, A.D. Pawlus, J.M. Merillon, Nat. Prod. Rep. 29, 1317-1333 (2012)

2. T. Shen, X.N. Wang, H.X. Lou, Nat. Prod. Rep. 26, 916-935 (2009)

3. P. Langcake, C.A. Cornford, R.J. Pryce, Phytochemistry 18, 1025-1027 (1979)

4. J.A. Sirerol, M.L. Rodríguez, S. Mena, M.A. Asensi, J.M. Estrela, A.L. Ortega, Oxid. Med. Cell. Longev. 2016, 1-15 (2016)

5. X.F. Wang, C.S. Yao, J. Asian Nat. Prod. Res. 18, 376-407 (2016)

6. T. Szkudelski, K. Szkudelska, Biochim. Biophys. Acta 1852, 1145-1154 (2015)

7. T. Ahmed, S. Javed, A. Tariq, D. Šamec, S. Tejada, S.F. Nabavi, N. Braidy, S.M. Nabavi, Mol. Neurobiol. 54, 2622-2635 (2017)

8. G.Z. Xin, J.L. Zhou, L.W. Qi, P. Li, Comb. Chem. High Throughput Screen. 14, 93-103 (2011)

9. L. Hoffer, J.P. Renaud, D. Horvath, Comb. Chem. High Throughput Screen. 14, 500-520 (2011)

\section{Affiliations}

\section{Chen-Chen Zhang ${ }^{1,2,3} \cdot$ Chang-An Geng ${ }^{1,2} \cdot$ Ji-Jun Chen ${ }^{1,2,3}$ []}

1 State Key Laboratory of Phytochemistry and Plant Resources in West China, Kunming Institute of Botany, Chinese Academy of Sciences, 132\# Lanhei Road, Kunming 650201, Yunnan, People's Republic of China

2 Yunnan Key Laboratory of Natural Medicinal Chemistry, Kunming 650201, People's Republic of China
10. M. Zhou, H. Luo, Z. Li, F. Wu, C. Huang, Z. Ding, R. Li, Comb. Chem. High Throughput Screen. 15, 306-315 (2012)

11. R. Li, Z.J. Wu, F. Zhang, L.S. Ding, Rapid Commun. Mass Spectrom. 20, 157-170 (2006)

12. K. Ablajan, A. Tuoheti, Rapid Commun. Mass Spectrom. 27, 451-460 (2013)

13. W. Niu, X.H. Zhu, K. Yu, L. Li, Y. Sun, C. Li, J. Mass Spectrom. 47, 370-380 (2012)

14. L.M. Szewczuk, S.H. Lee, I.A. Blair, T.M. Penning, J. Nat. Prod. 68, 36-42 (2005)

15. N. Mulinacci, M. Innocenti, A.R. Santamaria, G.L. Marca, G. Pasqua, Rapid Commun. Mass Spectrom. 24, 2065-2073 (2010)

16. R. Moss, Q.Y. Mao, D. Taylor, C. Saucier, Rapid Commun. Mass Spectrom. 27, 1815-1827 (2013)

17. J.B. Jean-Denis, R. Pezet, R. Tabacchi, J. Chromatogr. A 1112, 263-268 (2006)

18. C.A. Geng, J.J. Chen, Nat. Prod. Bioprospect. 6, 297-303 (2016)
University of Chinese Academy of Sciences, Beijing 100049 , People's Republic of China 